\title{
The Effect of Leunca Fruit (Solanum nigrum Linn) Infusion in Inhibiting the Increase of Serum Glutamate Pyruvate Transaminase Level in $\mathrm{CCL}_{4}$ Induced Hepatitis Wistar Rats
}

\author{
Kuswinarti, ${ }^{1}$ Syifa Karmani, ${ }^{2}{\text { Coriejati } \text { Rita }^{3}}^{3}$ \\ ${ }^{1}$ Department of Biomedical Sciences Faculty of Medicine Universitas Padjadjaran, Indonesia, \\ ${ }^{2}$ Faculty of Medicine Universitas Padjadjaran, Indonesia, ${ }^{3}$ Department of Clinical Pathology \\ Faculty of Medicine Universitas Padjadjaran/Dr. Hasan Sadikin General Hospital \\ Bandung, Indonesia
}

\begin{abstract}
Background: Hepatitis may cause liver cell damage due to the oxidation processes and can be inhibited by antioxidant components. Antioxidant acts as hepatoprotector by slowing down the oxidation process. Leunca fruits (Solanum nigrum Linn) contain antioxidants such as vitamin C and flavonoid. This study aimed to explore the effect of Leunca fruit infusion to inhibit the increase of serum Glutamate Pyruvate Transaminase (SGPT) level in Wistar rats' blood.

Methods: This was an experimental study using male Wistar rats, conducted in the Animal Laboratory, Department of Pharmacology and Therapy, Faculty of Medicine, Universitas Padjadjaran between September-October 2012. The Hepatitis rats model was induced with carbon tetrachloride $\left(\mathrm{CCl}_{4}\right)$ in $10 \%$ paraffin intraperitoneally as much as $8 \mathrm{~mL} / \mathrm{kgBW}$ on day $8^{\text {th }}$. A $3 \mathrm{~mL}$ of leunca fruit infusion was given with a concentration of $22.5 \mathrm{~g}$, $45 \mathrm{~g}$, and $90 \mathrm{~g}$ per $100 \mathrm{~mL}$, respectively. On the $10^{\text {th }}$ day, serum was taken and SGPT was examined. Only food and distilled water were given to the negative control group. The result was analyzed by using a Kruskal-Wallis non-parametric test, followed by Mann-Whitney post hoc.

Results: There was a significant difference between the negative control and hepatitis positive control group ( $\mathrm{p}=0.009)$, indicating that the induction was successful. The dose $90 \mathrm{~g} / 100 \mathrm{~mL}$ leunca had a significant different in SGPT concentration $(p=0.047)$, suggesting that leunca fruit infusion had a significant effect on reduced SGPT level.

Conclusions: Leunca fruit infusion has a hepatoprotective effect by inhibiting the increase of the SGPT level in $\mathrm{CCl}_{4}$ induced rats. Studies on the leunca effectiveness in human hepatitis need further exploration.
\end{abstract}

Keywords: $\mathrm{CCl}_{4}$, hepatoprotective, Leunca, SGPT

\section{Introduction}

Hepatitis is caused by an inflammation in the hepatic cells which can damage both hepatocytes or hepatic mesenchymal tissue, leading to its function disruption. ${ }^{1}$ Hepatitis has become the attention of the medical world due to high prevalence in the world and also in Indonesia. According to the World Health Organization (WHO), the frequency of hepatitis B virus that infects the global population is about 2 billion; whereas hepatitis C infects 130-170 millions of population. ${ }^{2}$ In Indonesia ${ }^{3,4}$, the hepatitis $\mathrm{B}$ affects 13 million individuals while hepatitis $\mathrm{C}$ affects 7 million individuals.

There are various types of Hepatitis treatment, however, it also induce several adverse effects such as hypersensitivity reaction and cardiovascular disturbance. Therefore, herbal medicines become alternative treatments chosen by the Indonesians because of its natural materials, relatively easy to obtain and process, affordability, and less adverse effects. ${ }^{5}$

Solanum nigrum Linn have many chemical contents such as solanine, solamargine, solasodine, solanidine, solasonine, vitamin E, vitamin C, and flavonoid, useful to prevent many diseases like cancer for examples on cervical, breast, hepatic, and lung cancer; moreover, urinary tract infection, hypertension,

Correspondence: Kuswinarti, Department of Biomedical Sciences, Faculty of Medicine, Universitas Padjadjaran, Jalan Raya Bandung-Sumedang Km.21, Jatinangor, Sumedang, Indonesia, E-mail: wiwinsumarlan@yahoo.com 
hepatitis can make use of this component. ${ }^{6}$ Vitamin E, vitamin $\mathrm{C}$, and flavonoids are known antioxidants that protect cells from the negative effects of free radicals by bonding and stabilizes free radicals and by preventing, inhibiting, and slowing the oxidation process. ${ }^{7,8}$ Interestingly, study on leunca fruit extract has shown to have a significant hepatoprotective effect in rats. ${ }^{9,10}$

Carbon tetrachloride $\left(\mathrm{CCl}_{4}\right)$ is one of the hepatotoxins that is metabolized by the cytochrome enzyme p450. $\mathrm{CCl}_{4}$ will form trichloromethyl, a free radical which oxidizes the fatty acid polyenoic on cell membranes and forms radical lipid. ${ }^{11,12}$ Cell membrane damage causes a leak of intracellular enzymes such as serum glutamate pyruvate transaminase (SGPT) that can be detected in blood and may serve as a marker on hepatocytes damage. ${ }^{11}$ This study aimed to explore the effects of leunca fruit infusion on the SGPT level of Wistar rats after being induced with $\mathrm{CCl}_{4}$.

\section{Methods}

This study was conducted in the Animal Laboratory, Department of Pharmacology and Therapy, Faculty of Medicine, Universitas Padjadjaran, and Clinical Pathology Laboratory of the Open Treatment Unit, Universitas Padjadjaran, in the period of SeptemberOctober 2012 using a laboratory experimental study designs with total random sampling.

The leunca fruit (Solanum nigrum Linn) was obtained from Manoko, Lembang, Bandung, West Java, and processed in the Herbarium of Jatinangor, Plantation Taxonomy Laboratory, Department of Biology, Faculty of Mathematics and Natural Sciences, Universitas Padjadjaran. In brief, leunca fruit was cleansed, cut and weighed according to the used concentration. The infusion was made by adding $100 \mathrm{~mL}$ water on the Simplicia, which was heated $\left(90^{\circ} \mathrm{C}\right)$ for 15 minutes and stirred once every 5 minutes. The infusion was let to cool in ambient temperature and filtered using flannel; hot

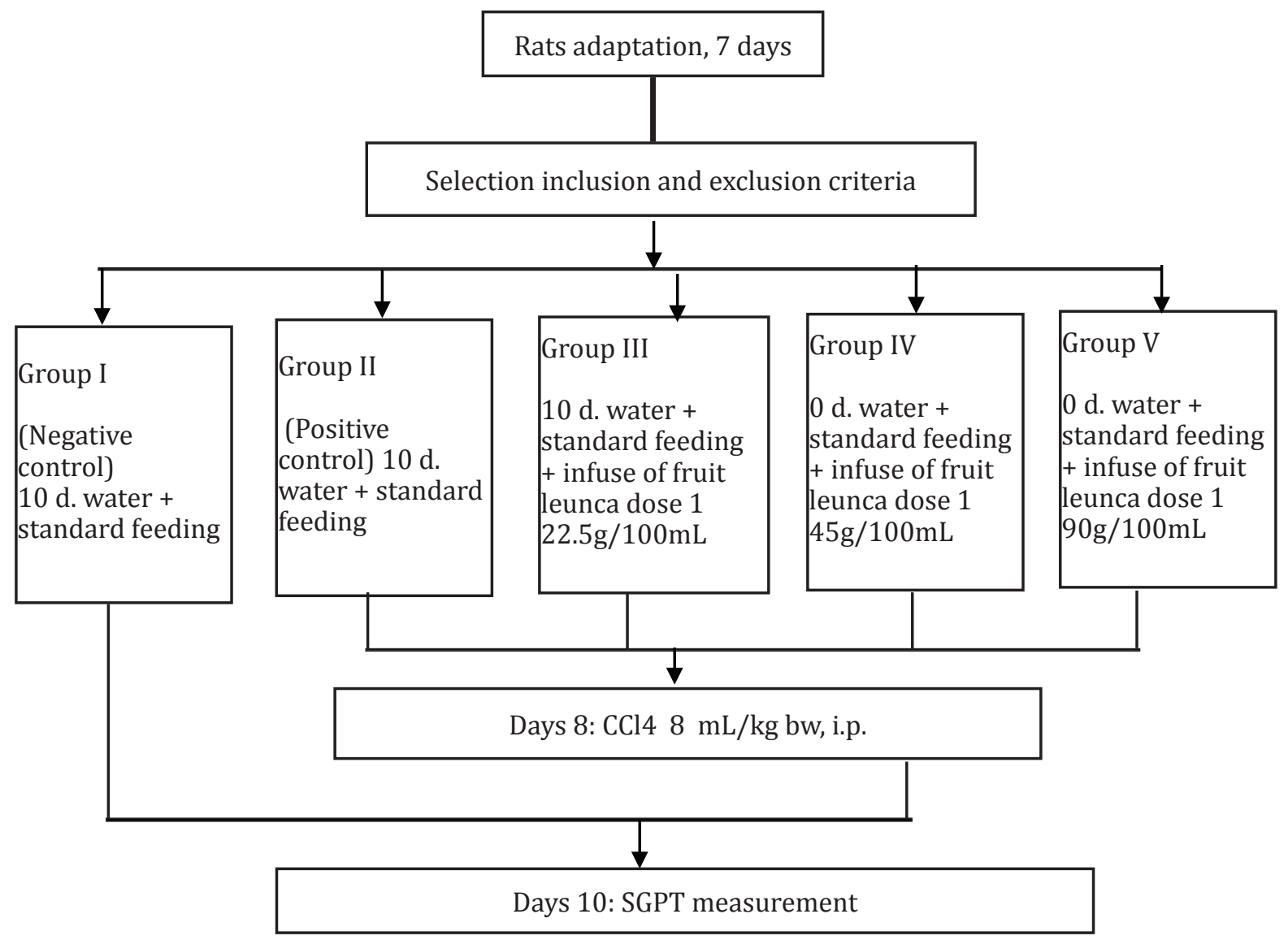

Figure 1 Flow of Research Study

Althea Medical Journal. 2019;6(4) 
Table The Level of Serum Glutamate Pyruvate Transaminase of Wistar Rats Induced with $\mathrm{CCl}_{4}$ After Leunca Fruit Infusion Treatment

\begin{tabular}{cccccc}
\hline Rats no. & $\begin{array}{c}\text { Negative } \\
\text { control }\end{array}$ & $\begin{array}{c}\text { Positive } \\
\text { control }\end{array}$ & $\begin{array}{c}\text { Leunca Infusion } \\
22.5 \mathrm{~g} / 100 \mathrm{~mL}\end{array}$ & $\begin{array}{c}\text { Leunca Infusion } \\
45 \mathrm{~g} / 100 \mathrm{~mL}\end{array}$ & $\begin{array}{c}\text { Leunca Infusion } \\
90 \mathrm{~g} / 100 \mathrm{~mL}\end{array}$ \\
\hline 1 & 83 & 1766 & 1139 & 952 & 534 \\
2 & 103 & 695 & 109 & 86 & 94 \\
3 & 83 & 1533 & 421 & 460 & 592 \\
4 & 77 & 1732 & 535 & 172 & 609 \\
5 & 85 & 483 & 529 & 994 & 121 \\
Mean & 86.2 & 1241.8 & 546.6 & 532.8 & 390 \\
\hline
\end{tabular}

Note: The level of serum Glutamate Pyruvate Transaminase (SGPT) was in presented in IU/L

water was added to the resulting base in the pot as much as the water lost in evaporation and filtering.

Male rats of Wistar strain aged 8-12 weeks weighted 180-200 g were retrieved from the Inter University Central Laboratory of Life Sciences (PAU), Institute of Technology Bandung and adapted for 7 days with a standard environmental condition of the Animal Laboratory, Department of Pharmacology and Therapy, Faculty of Medicine, Universitas Padjadjaran. Rats were given standard feeding and drinking, according to the ethical principle including reduction, refinement, and replacement on experimental animals. ${ }^{13}$

Furthermore, rats were randomly assigned into 5 groups, each of 5 rats as shown in figure 1. Group 1 was a negative control, whereas group 2 was a control positive and together with group 3,4 , and 5 were given an infusion of leunca fruit orally between the $1^{\text {st }}$ to $8^{\text {th }}$ day of experiment, with a volume of $3 \mathrm{~mL}$ in concentration of $22.5 \mathrm{gram} / 100 \mathrm{~mL}, 45 \mathrm{gram} / 100 \mathrm{~mL}$, and 90 gram $/ 100 \mathrm{~mL}$, respectively. 0 n the $8^{\text {th }}$ day, rats were injected intraperitoneal with $\mathrm{CCl}_{4}$, (Merck, Indonesia) 10\% within liquid paraffin at $8 \mathrm{~mL} / \mathrm{kgBW}$. On day $10^{\text {th }}$, all rats have fasted before measurement for the SGPT level. Rats have undergone an anasthesic procedure with ketamine, then blood was taken from the tail of the rats as much as 3 cc without anticoagulants. Blood was then centrifugated with a speed of $1000 \mathrm{rpm}$ for 10 minutes before SGPT measurement using a spectrophotometer.

Data were tested for normality test (SaphiroWilk) and homogeneity test (Levene) ensued. If the data were normally distributed and homogenous, analysis was continued with One way Analysis of Variance (ANOVA) test. If the analyzed was significantly different, then the Tukey test with a confidence interval of $95 \%$ was performed; otherwise, if the data was not normally distributed and heterogeneous, then analysis was performed using non-parametric test. The result was considered as significant if $\mathrm{p} \leq 0.05$.

The average of SGPT level obtained from 25 rats in the $10^{\text {th }}$ day is presented in Figure 1. The largest average was obtained from group II as positive control and the smallest in group I as negative control.

\section{Results}

After testing the normality of the data (Saphiro-Wilk test), it was shown that the data was not normally distributed. The variance homogeneity test using the Levene method gave a p-value of $0.001(\mathrm{p}<0.05)$ which showed heterogeneous data variance. Data that was not normally distributed and heterogeneous was tested with non-parametric test KruskalWallis, resulting in a p-value of $0.006(p<0.05)$ and thus there were significant differences between the tested groups. To know which group gave the most significant difference, an analytic test post hoc Mann-Whitney was performed, resulting in a statistically significant difference between the negative control and hepatitis positive control group $(p=0.009)$ indicating that the induction of $\mathrm{CCl}_{4}$ was successful (Table). Furthermore, the dose $90 \mathrm{~g} / 100 \mathrm{~mL}$ leunca had a significant difference in SGPT concentration $(p=0.047)$ suggesting that leunca fruit infusion had a lowering effect of SGPT level.

\section{Discussion}

This study was successful to make an animal model, in this case, Wistar rats, to have inflammatory hepatitis induced by $\mathrm{CCl}_{4}$, and this hepatitis model was confirmed by an increase of SGPT level. The induction of $\mathrm{CCl}_{4}$ as a hepatotoxin caused damage to the 
hepatic cells by forming trichloromethyl $\left(\mathrm{CCl}^{3-}\right)$ which was a reactive free radical after being activated by p450 of hepatic cells. ${ }^{9}$ Trichloromethyl initiated a lipid oxidation process on phospholipids, resulting in aldehyde which was toxic to cells. Both factors could cause damage on hepatic cell membrane and increase the activity of its intracellular enzymes such as SGPT. Serum Glutamate Pyruvate Transaminase (SGPT) detected in serum can be used as a sensitive indicator for hepatic damage, leading to a significant SGPT level rise in positive control group. ${ }^{10}$

Some concentration leunca fruit infusion has been tested, all have a decreasing effect of SGPT level, hence, no significant difference of leunca fruit infusion concentration for 22.5 $\mathrm{g} / 100 \mathrm{~mL}$ and $45 \mathrm{~g} / 100 \mathrm{~mL}$, respectively. However, with a concentration of $90 \mathrm{~g} / 100$ $\mathrm{mL}$, it has a significant effect on the decrease of SGPT. Leunca fruit has antioxidant substances, such as vitamin $\mathrm{C}$ and flavonoid which are known to be hepatoprotective. Flavonoid is an antioxidant that can prevent hepatic damage caused by the oxidation process. ${ }^{7,8}$ Vitamin $\mathrm{C}$ and flavonoid are of the group primary antioxidant which will react and change radical lipids into a stable products that can oxidize the fat of phospholipids in cellular membranes and organelles. ${ }^{7,8,12}$ This causes SGPT to leak into the sinusoid and cause inhibition on the rise of SGPT in serum which indirectly demonstrated that leunca fruit infusion has a hepatoprotective active compound, suggesting that leunca fruit extract have a hepatoprotective effect by inhibiting the rise of SGPT on $\mathrm{CCl}_{4}$ induced rats. ${ }^{14}$ Similarly, our previous study using Annona muricata Linn. The leaf has also an effect in inhibitory SGPT elevation. ${ }^{15}$

The limitation of this study is that this study only has three concentrations of infusion. To conclude, the administration of leunca fruit infusion (Solanum nigrum Linn.) with a dose of 90 grams $/ 100 \mathrm{~mL}$ on Wistar rats can inhibit the rise of SGPT significantly. Further research is needed to explore the optimal dose and the toxicity concentration of leunca fruit infusion, to make possible for leunca fruit to be regarded as phytopharmaca.

\section{References}

1. Robbins SL, Kumar V, Abbas AK, Cotran RS, Fausto N. Robbins and cotran pathologic basis of disease. $8^{\text {th }}$ ed. Philadelphia: Saunders/Elsevier; 2010.

2. World Health Organization. Viral hepatitis.
Geneva: World Health Organization; 2010

3. Kementrian Kesehatan Republik Indonesia. Lembar fakta hepatitis. 2010 [Cited 2012 March 14]; Available from: http:// www.depkes.go.id/hepatitis/index.php/ component/content/article/34-pressrelease/799-lembar-fakta-hepatitis.html.

4. Kementrian Kesehatan Republik Indonesia. Saatnya lawan hepatitis. 2010. [Cited 2012 March 23]; Available from: http://www. depkes.go.id/index.php/component/ content/article/43-newsslider/1557saatnya-lawan-hepatitis.html.

5. Govind P. Medicinal plants against liver diseases. IRJP. 2011;2(5):115-21.

6. Hartati K, Ruslan K, Fidrianny I. Telaah kandungan kimia buah leunca (Solanum nigrum L.). [thesis]. Bandung: Institut Teknologi Bandung; 2005.

7. Hamid AA, Aiyelaagbe 00, Usman LA, Ameen OM, Lawal A. Antioxidants: Its medicinal and pharmacological applications. Afr J Pure Appl Chem. 2010;4(8):142-51.

8. Mohy-Ud-Din A, Khan ZUD, Ahmad M, Kashmiri MA. Chemotaxonomic value of alkaloids in solanum nigrum complex. Pak J Bot. 2010;42(1):653-60.

9. Zulaikhah ST. The Role of antioxidant to prevent free radicals in the body. Sains Medika. 2017; 8(1):39-45

10. Elhag RAM, El Badwi SMAE, Bakhiet AO, Galal M. Hepatoprotective activity of Solanum nigrum extracts on chemically induced liver damage in Rats. J Vet Med Anim Health. 2011;3(4):45-50

11. Sahreen S, Khan MR, Khan RA. Hepatoprotective effects of methanol extract of Carissa opaca leaves on CCl4induced damaged in rat. BMC Complement Altern Med. 2011;11:48.

12. Panjaitan RGP, Handharyani E, Chairul, Masriani, Zakiah Z, Manalu W. Pengaruh pemberian karbon tetraklorida terhadap fungsi hati dan ginjal tikus. Makara, Kesehatan. 2007;11(1):11-6.

13. Buchanan-Smith H, Rennie AE, Vitale A, Pollo S, Prescott MJ, Morton DB. Harmonising the definition of refinement. Animal Welfare. 2005;14:379-84.

14. Raju K, Anbuganapathi G, Gokulakrishnan V, Rajkapoor B, Jayakar B, Manian S. Effect of dried fruits of Solanum nigrum Linn against CCl4-induced hepatic damage in rats. Biol Pharm Bull. 2003;26(11):16189.

15. Tanaya G, Kuswinarti, Dewi NS. Annona muricata Linn. Leaf effect in inhibitory SGPT elevation. AMJ. 2015; 2(1):86-9. 